\title{
A Step Forward Towards Exploring Nutritional and Biological Potential of Mushrooms: A Case Study of Calocybe gambosa (Fr.) Donk Wild Growing in Serbia
}

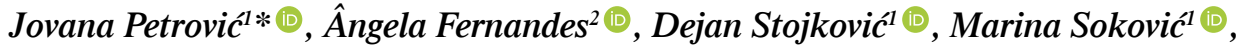 \\ Lillian Barros $^{2}{ }^{\oplus}$, Isabel C.F.R. Ferreira ${ }^{2}{ }^{\oplus}$, Aditya Shekhar ${ }^{3}{ }^{\oplus}$, Jasmina Glamočlija $^{1}{ }^{\oplus}$ \\ 'Institute for Biological Research "Siniša Stanković", National Institute of Republic of Serbia, University of Belgrade, \\ Bulevar despota Stefana 142, 11000 Belgrade, Serbia \\ ${ }^{2}$ Centro de Investigação de Montanha (CIMO), Instituto Politécnico de Bragança, Campus de Santa Apolónia, \\ 5300-253, Bragança, Portugal \\ ${ }^{3}$ Helmholtz Centre for Infection Research, Inhoffenstraße 7, 38124 Braunschweig, Germany
}

Key words: $C$. gambosa, nutritional value, biological activity, chemical characterization, food ingredient

Edible mushrooms have been appreciated globally for their organoleptic, nutritional and chemical properties. In the present study, fruiting body of Calocybe gambosa, wild growing in Serbia, has been chemically characterized (content of macronutrients, soluble sugars, tocopherols, fatty and organic acids) and its bioactive (antimicrobial and antioxidant) properties were evaluated. The results obtained suggest that this mushroom is a source of carbohydrates and proteins $(72 \mathrm{~g} / 100 \mathrm{~g}$ dry weight $(\mathrm{dw})$ and $16 \mathrm{~g} / 100 \mathrm{~g} \mathrm{dw}$, respectively), with a low fat content $(1.5 \mathrm{~g} / 100 \mathrm{~g}$ dw). Sugar analysis revealed the presence of trehalose $(3.82 \mathrm{~g} / 100 \mathrm{~g} \mathrm{dw})$ and mannitol $(0.22 \mathrm{~g} / 100 \mathrm{~g} \mathrm{dw})$. Tocopherol composition revealed the presence of $\alpha$-tocopherol $(7.8 \mu \mathrm{g} / 100 \mathrm{~g} \mathrm{dw})$, while fatty acid analysis revealed the presence of 24 fatty acids with the prevalence of polyunsaturated fatty acids. Amongst organic acids, oxalic, quinic, malic, citric and fumaric acid were detected $(2.8 \mathrm{~g} / 100 \mathrm{~g} \mathrm{dw}, 1.45 \mathrm{~g} / 100 \mathrm{~g} \mathrm{dw}, 11.3 \mathrm{~g} / 100 \mathrm{~g} \mathrm{dw}, 1.3 \mathrm{~g} / 100 \mathrm{~g} \mathrm{dw}, 0.08 \mathrm{~g} / 100 \mathrm{~g} \mathrm{dw}$, respectively). Comprehensive antioxidant activity analysis (reducing power, DPPH radical scavenging activity, $\beta$-carotene/linoleate and TBARS assays) indicate that the mushroom is a perspective antioxidant source, whereas its antimicrobial potential turned out to be moderate. Nevertheless, at a sub-inhibitory level, the methanolic extract disrupted cell-to-cell communication using Pseudomonas aeruginosa PAO1 as a model system. Finally, enrichment of oatmeal cookies with $C$. gambosa flakes not only improved their nutritional value, but was praised among the participants in sensory evaluation test, indicating that along with results of chemical composition and biological activity, this mushroom has a potential to be regarded as functional food.

\section{INTRODUCTION}

Wild edible mushrooms have been appreciated worldwide for their unique odor, taste and texture, as well as their beneficial nutritional and chemical properties [Barroetaveña \& Toledo, 2017]. They have been used as food by Chilean tribes 13,000 years ago, whereas the most comprehensive data on their medicinal use are 3,000 years old and come from traditional Chinese medicine.

Until recently, use of mushrooms for medicinal purposes has been marginalized in Western countries, while only their organoleptic properties have been appreciated. Nowadays, the situation has changed significantly, as is indicated by extensive research studies in the field of medical mycology [Valverde et al., 2015]. Furthermore, a favorable nutritional profile (including high contents of carbohydrates and proteins, and a low lipid level) along with the presence of biologically active compounds, including phenolics, terpenoids, steroids, lectins, etc., highlight the potential of mushrooms to be regarded as functional food [Barroetaveña \& Toledo, 2017; Rathee et al., 2012].

The discovery of therapeutics with antimicrobial activity at the beginning of the $\mathrm{XX}^{\text {th }}$ century significantly improved treatment of infections caused by pathogenic microorganisms, reduced the mortality rate, and contributed to the prolongation of human life. Nevertheless, due to their unreasonable and excessive use, a number of bacterial strains resistant to certain types of antibiotics has significantly risen [Zhong, 2009]. As to resolve this problem, the quest for new antimicrobial products has been reevaluated, with edible mushrooms emerging as an important source of compounds with this activity [Alves et al., 2012, 2013]. Over the last decade and more so, a large number of mushrooms have been tested with the aim of finding substances with antimicrobial potential [Alves et al., 2012, 2013; Barros et al., 2007]. Results of studies have shown that mushrooms are rich in polysaccharides,

\footnotetext{
* Corresponding Author:

Tel.: +381 112078 419;

E-mail: jovana0303@ibiss.bg.ac.rs (J. Petrović)
} 
phenolics, terpenoids, sterols, organic acids, anthraquinone derivatives, peptides, proteins, and ribonucleases, and as such may be used for the development of new antimicrobial, antitumor, antineurodegenerative, and antidiabetic therapeutics; and finally that they are a source of prophylactic antioxidants etc. [Alves et al., 2013; Petrović et al., 2020]. This has been substantiated with literature data which imply that as much as 130 different bioactivities may be attributed to various species of mushrooms [Wasser, 2014]. Therefore, this study was performed to determine the detailed nutritional value and chemical composition of wild Calocybe gambosa (Fr.) Donk collected in Serbia, as well as to assess the biological activities of the methanolic extract prepared. To check its potential to be incorporated in food products, a recipe for oatmeal cookies enriched with $C$. gambosa flakes was developed and cookies were subjected to sensory evaluation.

\section{MATERIALS AND METHODS}

\section{Mushroom collection and identification}

Fruiting bodies of wild growing mushroom $C$. gambosa (Fr.) Donk (Lyophyllaceae) were collected in Bežanija, near Belgrade, Serbia, and authenticated by Jasmina Glamočlija, $\mathrm{PhD}$, Institute for Biological Research "Siniša Stanković", National Institute of Republic of Serbia, University of Belgrade, Serbia. A voucher specimen has been deposited at the Fungal Collection Unit of the Mycological Laboratory, Department for Plant Physiology, Institute for Biological Research "Siniša Stanković", Belgrade, Serbia. The samples were freeze-dried (LH Leybold, Lyovac GT2, Frankendorf, Switzerland), reduced to a fine dried powder (20 mesh), mixed to obtain homogenous samples and stored at $4^{\circ} \mathrm{C}$, protected from light, until further analysis.

\section{Standards and reagents}

Acetonitrile 99.9\%, $n$-hexane 95\% and ethyl acetate $99.8 \%$ were of HPLC grade and purchased from Fisher Scientific (Lisbon, Portugal). The fatty acid methyl ester (FAME) reference standard mixture 37 (standard 47885-U) was purchased from Sigma (St. Louis, MO, USA), as well as other individual fatty acid isomers and standards of tocopherols, sugars, organic acids and 6-hydroxy-2,5,7,8-tetramethylchroman-2-carboxylic acid (Trolox). Racemic tocol, $50 \mathrm{mg} / \mathrm{mL}$, was purchased from Matreya (State College, PA, USA), while 2,2-diphenyl-1-picrylhydrazyl (DPPH) radical was obtained from Alfa Aesar (Ward Hill, MA, USA). Mueller-Hinton agar (MH) and malt agar (MA) were obtained from the Institute of Immunology and Virology, Torlak (Belgrade, Serbia). Methanol and other chemicals/solvents were of analytical grade and purchased from common sources. Water was treated in a Milli-Q water purification system (TGI Pure Water Systems, Greenville, SC, USA).

\section{Chemical composition analysis \\ Nutritional value and energy}

Fat, protein, and ash contents were determined acc. to the Association of Official Analytical Chemists (AOAC) procedures [AOAC, 2016]. The crude fat content was determined by Soxhlet extraction of the samples with petroleum ether. The ash content was determined by sample incineration at $550 \pm 15^{\circ} \mathrm{C}$. The crude protein content was analyzed using an automatic distillation and titration unit (Pro-Nitro-A model, JP Selecta, Barcelona, Spain) by the macro-Kjeldahl method $(\mathrm{N} \times$ correction factor, namely 4.38). The results were expressed in g per $100 \mathrm{~g}$ of dry weight $(\mathrm{dw})$. Total carbohydrates $(\mathrm{g} / 100 \mathrm{~g} \mathrm{dw})$ and energy (kcal/100 g dw) were calculated according to the following equations: $[100-(\mathrm{g}$ protein $+\mathrm{g}$ fat $+\mathrm{g}$ ash $)]$ and $[4 \times(\mathrm{g}$ protein + $\mathrm{g}$ carbohydrates $)+9 \times(\mathrm{g}$ fat $)$, respectively.

\section{Hydrophilic compounds}

Soluble sugars were analyzed using a high performance liquid chromatography (HPLC) system coupled to a refraction index (RI) detector as previously described by Reis et al. [2012a]. Briefly, the samples $(1 \mathrm{~g})$ were spiked with melezitose (internal standard, IS, $5 \mathrm{mg} / \mathrm{mL}$ ) and extracted with $80 \%(\mathrm{v} / \mathrm{v})$ ethanol at $80^{\circ} \mathrm{C}$. The mixture was centrifuged and the supernatant was concentrated and defatted with ethyl ether. After concentration at $40^{\circ} \mathrm{C}$, the residues were dissolved in $5 \mathrm{~mL}$ of water and filtered through $0.2 \mu \mathrm{m}$ nylon filters. Identification was achieved by comparing the peak retention times with those of the authentic standards, while quantification was based on the internal standard (IS) method, with calibration curves constructed with commercial standards. The results were expressed in $\mathrm{g}$ per $100 \mathrm{~g} \mathrm{dw}$.

The organic acids profile was analyzed by ultra-fast liquid chromatography (UFLC; Shimadzu 20A series, Kyoto, Japan) following a procedure previously described and optimized by the authors [Barros et al., 2013]. Briefly, the samples (1 g) were stirred with $25 \mathrm{~mL}$ of metaphosphoric acid for $45 \mathrm{~min}$ and filtered, first through Whatman No. 4 filter paper and then through $0.2 \mu \mathrm{m}$ nylon filters. Chromatographic separation was achieved in reverse phase on a C18 column ( $5 \mu \mathrm{m}$ particle size, $250 \times 4.6 \mathrm{~mm}$; Phenomenex, Torrance, CA, USA). Detection was performed in a photo-diode array detector (PDA), at $215 \mathrm{~nm}$. The detected compounds were identified and then quantified by chromatographic comparison of the peak area with calibration curves obtained from commercial standards. The results were expressed in $\mathrm{g}$ per $100 \mathrm{~g} \mathrm{dw}$.

\section{Lipophilic compounds}

After transesterification of the lipid fraction obtained by Soxhlet extraction [Reis et al., 2012a], the fatty acid methyl ester (FAME) mixture was analyzed by gas-liquid chromatography (GC) with flame ionization detection, using a YOUNG IN Chromass 6500 GC system (Anyang, South Korea) apparatus equipped with a split/splitless injector, a flame ionization detector (FID), and a Zebron-Fame column (Phenomenex). Identification was made by chromatographic comparison of the retention times of the FAME peaks with those of the standard $47885-\mathrm{U}$. The results were recorded and processed using Clarity DataApex 4.0 software (Prague, Czech Republic) and the content of each fatty acid was expressed as percentage of total fatty acids.

Tocopherols were analyzed according to a procedure described by Heleno et al. [2010], using the HPLC system coupled to a fluorescence detector (FP-2020; Jasco, Tokyo, Japan), programmed for excitation at $290 \mathrm{~nm}$ and emission at $330 \mathrm{~nm}$. Briefly, the samples $(500 \mathrm{mg})$ were spiked with 
a butylated hydroxytoluene solution $(10 \mathrm{mg} / \mathrm{mL})$ and tocol (IS, $2 \mu \mathrm{g} / \mathrm{mL}$ ), and homogenized first with $4 \mathrm{~mL}$ of methanol and then with $4 \mathrm{~mL}$ of $n$-hexane. Then, $2 \mathrm{~mL}$ of a saturated $\mathrm{NaCl}$ aqueous solution were added, the mixture was homogenized and centrifuged, and the upper layer was collected. The extraction was repeated twice with $n$-hexane. The extracts were dried under a nitrogen stream, redissolved in $1 \mathrm{~mL}$ of $n$-hexane, dehydrated, and filtered through $0.22 \mu \mathrm{m}$ syringe filters. Chromatographic separation was performed in normal phase on a Polyamide II column ( $5 \mu \mathrm{m}$ particle size, $250 \times 4.6 \mathrm{~mm}$; YMC, Kyoto, Japan). Identification was made by chromatographic comparison with authentic standards, and quantification was based on the fluorescence signal response of each standard, using the IS (tocol) method and calibration curves constructed from commercial standards. The results were expressed in $\mu \mathrm{g}$ per $100 \mathrm{~g}$ of dw.

\section{Preparation of extract}

Extract was prepared from lyophilized mushroom powder using methanol (Merck, Darmstadt, Germany) as a solvent according to a procedure earlier published by Vaz et al. [2010]. Briefly, $10 \mathrm{~g}$ of mushroom powder was used for the extraction with $240 \mathrm{~mL}$ of methanol overnight at $-20^{\circ} \mathrm{C}$. The extract was then sonicated for $15 \mathrm{~min}$ in an ultrasonic bath (Bandelin sonorex, Berlin, Germany) and centrifuged for $10 \mathrm{~min}$ at $4,000 \times g$ and $4^{\circ} \mathrm{C}$ (Heraeus Biofuge Stratos centrifuge, Thermo Electron Corporation, Waltham, MA, USA). The extract was filtered through Whatman No. 4 filter paper, and the precipitate was re-extracted in an ultrasonic bath three times with $100 \mathrm{~mL}$ of methanol each. The combined supernatant was evaporated to dryness at $40^{\circ} \mathrm{C}$ using a rotary vacuum evaporator (Büchi R-210, Flawil, Germany). The extract was stored at $4^{\circ} \mathrm{C}$ until further use.

\section{Antioxidant activity determination}

Five assays were used for the evaluation of in vitro antioxidant activity: ferricyanide/Prussian blue assay, DPPH radical scavenging activity assay, $\beta$-carotene/linoleate assay and thiobarbituric acid reactive substances (TBARS) assay. Moreover, the Folin-Ciocalteu assay was used to evaluate the total phenolic content. For the assays, a stock solution was used to make successive dilutions [Reis et al., 2012b]. The concentrations of the samples that provided $50 \%$ of antioxidant activity or 0.5 of absorbance $\left(\mathrm{EC}_{50}\right.$ and $\mathrm{EC}_{0.5}$, respectively) were calculated from the obtained graphical results $(\mathrm{DPPH}$, $\beta$-carotene/linoleate and TBARS assays) or absorbance at $690 \mathrm{~nm}$ (ferricyanide/Prussian blue assay) against sample concentrations. Trolox was used as a standard.

Total phenolic content (Folin-Ciocalteu assay) was determined according to the procedure described by Reis et al. [2012b], with gallic acid used to obtain the standard curve. Results were expressed as mg of gallic acid equivalents (GAE) per g of extract.

\section{Antimicrobial activity determination \\ Antibacterial assay \\ The Gram-positive bacteria Staphylococcus aureus (ATCC 6538), Bacillus cereus (clinical isolate), Micrococcus luteus (ATCC 10240) and Listeria monocytogenes (NCTC 7973),}

as well as Gram-negative bacteria Pseudomonas aeruginosa (ATCC 27853), Salmonella Typhimurium (ATCC 13311), Escherichia coli (ATCC 35210), and Enterobacter cloacae (human isolate), were used. The microorganisms were obtained from the Mycological Laboratory, Department of Plant Physiology, Institute for Biological Research "Siniša Stankovič", University of Belgrade, National Institute of Republic of Serbia. The antibacterial assay was carried out by a modified microdilution method [CLSI, 2009]. The lowest concentrations that showed a distinct reduction in color intensity - light red in comparison to the intensive red in the control well (with no added extract), or an absence of color (clear yellow solution of the well), were defined as minimal inhibitory concentration (MICs). The minimal bactericidal concentrations (MBCs) were determined by serial sub-cultivation of $2 \mu \mathrm{L}$ into the wells already containing $100 \mu \mathrm{L}$ of broth and further incubation for $24 \mathrm{~h}$ at $37^{\circ} \mathrm{C}$. The lowest concentration with no visible growth was defined as the MBC, indicating $99.5 \%$ killing of the original inoculum.

\section{Antifungal assay}

The following micromycetes were used for the evaluation of antifungal activity: Aspergillus fumigatus (ATCC 1022), Aspergillus versicolor (ATCC 11730), Aspergillus ochraceus (ATCC 12066), Aspergillus niger (ATCC 6275), Trichoderma viride (IAM 5061), Penicillium funiculosum (ATCC 36839), Penicillium ochrochloron (ATCC 9112) and Penicillium verrucosum var. cyclopium (food isolate). The lowest concentrations with significant reduction in mycelial growth (at the binocular microscope) were defined as MICs. The minimal fungicidal concentrations (MFCs) were determined by serial sub-cultivation of a $2 \mu \mathrm{L}$ of the tested sample dissolved in medium and further incubated for $72 \mathrm{~h}$ at $25^{\circ} \mathrm{C}$. The lowest concentration with no visible growth was defined as MFC indicating $99.5 \%$ killing of the original inoculum.

\section{Anti-quorum sensing (QS) activity determination}

Bacterial strains, growth media and culture conditions

P. aeruginosa PA01 (ATCC 27853) was cultured overnight in Lysogeny broth (LB) medium ( $1 \% w / v \mathrm{NaCl}, 1 \% w / v$ Tryptone, $0.5 \% \mathrm{w} / \mathrm{v}$ yeast extract) with shaking $(220 \mathrm{rpm})$ at $37^{\circ} \mathrm{C}$.

\section{Twitching and flagella motility}

These features were determined following a procedure described by Yeo \& Tham [2012] to estimate the potential of the mushroom extract to alter structures type IV pili (TIVP) necessary for $P$. aeruginosa PAO1 motility (which consequently leads to colony dispersion and colonization of the host). The experiment was done in triplicate. Length of TIVP was estimated under the binocular microscope (type 020-518.500 DM LS, Leica, Wetzlar, Germany). Streptomycin and ampicillin used as positive controls were purchased from Zorka Pharma (Šabac, Serbia). The extract was tested at $0.5 \mathrm{MIC}$ value $-21.9 \mathrm{mg} / \mathrm{mL}$, while the positive controls were tested at $0.10 \mathrm{mg} / \mathrm{mL}$.

\section{Pyocyanin production inhibition}

The potential inhibitory effect of the mushroom extract towards the production of pyocyanin (virulence factor 
of PAO1) was evaluated using the method described by El Fouly et al. [2015]. Antibiotics: streptomycin and ampicillin (Zorka Pharma), were used as positive controls in the concentration $0.10 \mathrm{mg} / \mathrm{mL}$, while the concentration of the extract was $0.5 \mathrm{MIC}$ value $-21.9 \mathrm{mg} / \mathrm{mL}$. The results were calculated according to equation: $\mathrm{I}(\%)=\left[\left(\mathrm{OD}_{\mathrm{c}}-\mathrm{OD}_{\mathrm{s}}\right) / \mathrm{OD}_{\mathrm{c}}\right] \times 100$ with optical density (OD) measured on spectra from $520 \mathrm{~nm}$ to $600 \mathrm{~nm}$, reaching its maximum at $520 \mathrm{~nm}\left(\mathrm{OD}_{\mathrm{c}}-\right.$ optical density of the control pyocyanin, $\mathrm{OD}_{\mathrm{s}}$ - optical density of the extract/antibiotics).

\section{Preparation of the oatmeal cookies enriched with C. gambosa flakes}

For the preparation of oatmeal cookies, $60 \mathrm{~g}$ of softened butter was mixed with $170 \mathrm{~g}$ of castor sugar, 1 large egg $(\sim 50 \mathrm{~g}), 120 \mathrm{~g}$ of self-rising flour, $50 \mathrm{~g}$ of rolled oats and $25 \mathrm{~g}$ of $C$. gambosa flakes. As for the seasoning, $2.50 \mathrm{~g}$ of salt, $2.50 \mathrm{~g}$ of vanilla extract, $2.50 \mathrm{~g}$ of grounded cinnamon and $75 \mathrm{~g}$ of chocolate chips ( $70 \%$ cocoa) were added to the mixture. The mixture was poured with ice cream scoop onto the pane and baked at $180^{\circ} \mathrm{C}$ for $20 \mathrm{~min}$, or until golden brown. In total, with this recipe, we obtained 24 cookies which after the baking weighed approximately $25 \mathrm{~g}$ each.

\section{Sensory evaluation and nutritional value determination of cookies}

The sensory evaluation of the freshly baked product was attended by 24 untrained participants. Oatmeal cookies without $C$. gambosa flakes were used as a positive control, and were evaluated by the participants in relation to the mushroom-enriched product. Participants were asked to evaluate overall acceptability, appearance, aroma, taste and consistency of oatmeal cookies alone and those enriched with $C$. gambosa flakes on a scale 1-5 (1 - extremely dislike, 2 - dislike, 3 - neither like nor dislike, 4 - like, 5 - extremely like). Results were averaged by number of participants. The nutritional value of oatmeal cookies was determined, based on the nutritional value of the ingredients. Furthermore, the nutritional value (the content of fat, proteins and carbohydrates) of the mushroom-enriched cookies was calculated taking into account the nutritional value of the cookie ingredients as well as the nutritional value of $C$. gambosa flakes, determined in our study.

\section{Statistical analysis}

All the performed assays were carried out in triplicate, and their results were expressed as mean values and standard deviation.

\section{RESULTS AND DISCUSSION}

\section{Chemical composition of $\boldsymbol{C}$. gambosa}

Nutritional value and hydrophilic compounds

Nutritional value analysis (Table 1) revealed that the wild growing C. gambosa collected in Serbia is rich in carbohydrates $(72 \mathrm{~g} / 100 \mathrm{~g} \mathrm{dw})$, followed by proteins $(16 \mathrm{~g} / 100 \mathrm{~g}$ $\mathrm{dw})$, and has a low total fat content $(1.5 \mathrm{~g} / 100 \mathrm{~g} \mathrm{dw})$, resulting in energy value of $365 \mathrm{kcal} / 100 \mathrm{~g} \mathrm{dw}$. A few studies exploring the nutritional potential of $C$. gambosa (commonly known as St. George mushroom) indicate that the level
TABLE 1. Nutritional value and contents of hydrophilic compounds $(\mathrm{g} / 100 \mathrm{~g} \mathrm{dw})$ of Calocybe gambosa.

\begin{tabular}{|c|c|c|}
\hline & Component/compound & Content \\
\hline \multirow{5}{*}{$\begin{array}{l}\text { Nutritional } \\
\text { value }\end{array}$} & Ash & $10.6 \pm 0.9$ \\
\hline & Proteins & $16 \pm 2$ \\
\hline & Fat & $1.5 \pm 0.3$ \\
\hline & Carbohydrates & $72 \pm 1$ \\
\hline & Energy (kcal/100 g dw) & $365 \pm 2$ \\
\hline \multirow{3}{*}{$\begin{array}{l}\text { Soluble } \\
\text { sugars }\end{array}$} & Mannitol & $0.22 \pm 0.01$ \\
\hline & Trehalose & $3.82 \pm 0.04$ \\
\hline & Total sugars & $4.04 \pm 0.04$ \\
\hline \multirow{6}{*}{$\begin{array}{l}\text { Organic } \\
\text { acids }\end{array}$} & Oxalic acid & $2.8 \pm 0.2$ \\
\hline & Quinic acid & $1.45 \pm 0.04$ \\
\hline & Malic acid & $11.3 \pm 0.7$ \\
\hline & Citric acid & $1.3 \pm 0.2$ \\
\hline & Fumaric acid & $0.08 \pm 0.01$ \\
\hline & Total & $16.9 \pm 0.6$ \\
\hline
\end{tabular}

Data represent mean \pm standard deviation; dw: dry weight.

of macronutrients may vary greatly, depending on the origin of the tested sample [Barroetaveña \& Toledo, 2017].

Comparative analysis of the samples originating from Serbia and Croatia suggested the following: a sample from Croatia [Beluhan \& Ranogajec, 2011] had almost twice the value of protein content $(36.65 \mathrm{~g} / 100 \mathrm{~g} \mathrm{dw})$ than Serbian sample obtained in this study $(16 \mathrm{~g} / 100 \mathrm{~g} \mathrm{dw})$, but rather similar fat content $(1.34 \mathrm{~g} / 100 \mathrm{~g} \mathrm{dw}$ and $1.5 \mathrm{~g} / 100 \mathrm{~g}$ dw for the Croatian and Serbian sample, respectively). The main difference among the two samples was in the carbohydrate content (72 g/100 g dw in Serbian, $42.65 \mathrm{~g} / 100 \mathrm{~g} \mathrm{dw}$ in Croatian), which eventually determined a higher energy value of the sample collected in Serbia. This leads to the conclusion that the nutritional value may show strong discrepancy even though climatic and geographic conditions are similar. Furthermore, according to Vaz et al. [2011], the Portuguese sample was rather rich in proteins ( $15.46 \mathrm{~g} / 100 \mathrm{~g}$ of dw), ash $(13.89 \mathrm{~g} / 100 \mathrm{~g}$ of $\mathrm{dw})$, while the contents of fat $(0.83 \mathrm{~g} / 100 \mathrm{~g}$ of $\mathrm{dw})$, carbohydrates $(69.83 \mathrm{~g} / 100 \mathrm{~g}$ of $\mathrm{dw})$ and energy (348.58 kcal/100 g dw) were rather lower than the values determined in the present study. Moreover, a sample collected in India was rather rich in proteins $(20.22 \mathrm{~g} / 100 \mathrm{~g} \mathrm{dw})$ with somewhat lower total carbohydrate content than the previously mentioned samples - $65.61 \mathrm{~g} / 100 \mathrm{~g} \mathrm{dw}$ [Mridu \& Atri, 2017]. Altogether, C. gambosa may be considered a desirable food in several dietary regimens used to achieve blood lipid level homeostasis, as well as to obtain all the necessary nutrients. Regarding soluble sugar composition (Table 1), the results obtained did not diverge from the values usually observed for wild growing mushrooms; trehalose was the most abundant sugar with $3.82 \mathrm{~g} / 100 \mathrm{~g} \mathrm{dw}$, followed by mannitol which was present in rather low amount $(0.22 \mathrm{~g} / 100 \mathrm{~g} \mathrm{dw})$. As for the soluble sugar content in samples of different origin, 
compared to the Serbian sample (Table 1), a sample collected in Croatia [Beluhan \& Ranogajec, 2011] had approximately similar mannitol content $(0.34 \mathrm{~g} / 100 \mathrm{~g} \mathrm{dw})$, while the trehalose content $(7.69 \mathrm{~g} / 100 \mathrm{~g} \mathrm{dw})$ was almost twice the level determined for the sample collected in Serbia. Furthermore, mannose and glucose were identified only in the Croatian sample, which resulted in its significantly higher total sugar content (36.39 g/100 g dw) in comparison to $4.04 \mathrm{~g} / 100 \mathrm{~g} \mathrm{dw}$ determined for the Serbian sample. A similar content of mannitol was identified in a study conducted by Vaz et al. [2011], while the trehalose level $(7.96 \mathrm{~g} / 100 \mathrm{~g} \mathrm{dw})$ was significantly higher than the value obtained in this study. In the present study, among the identified organic acids, malic and oxalic acid were the most abundant $(11.3 \mathrm{~g} / 100 \mathrm{~g} \mathrm{dw}$ and $2.8 \mathrm{~g} / 100 \mathrm{~g} \mathrm{dw}$, respectively), whereas contents of the other identified organic acids were significantly lower (Table 1).

\section{Lipophilic compounds}

Among identified tocopherols, $\alpha$-tocopherol $(7.8 \mu \mathrm{g} / 100 \mathrm{~g}$ $\mathrm{dw}$ ) was the only identified tocopherol isomer (Table 2). Regarding fatty acid analysis (Table 2), 24 acids were identified in total, with polyunsaturated $\omega-6$ linoleic acid as the most abundant among the identified (75.1\% of the total fatty acids). Additionaly, polyunsaturated fatty acids (PUFA) predominated over saturated (SFA) and monounsaturated (MUFA) fatty acids, $75.8 \%$ over $20.2 \%$ and $3.98 \%$ respectively. Compared to the other published results of $C$. gambosa fatty acid profile, Vaz et al. [2011] reported a high proportion of linoleic acid in a Portuguese wild growing sample, while data regarding samples collected from other geographic regions are not available. Even though a fair amount of SFA was determined as well (palmitic acid, 13.2\%), the prevalence of PUFA over SFA and MUFA, along with a total low fat content indicates that the $C$. gambosa is a desirable food in dietary regimens, when controlled intake of fat is required. According to Barroetaveña \& Toledo [2017], the prevalence of PUFA over MUFA and SFA was also recorded in other species, with rather high values of linoleic acid measured in Coprinus comatus (74.86\%), Calvatia utriformis (70.29\%) and Agaricus campestris $(68.97 \%)$, with the exception is Lactarius deliciosus whose fruiting body contains a significant amount of stearic acid [Ferreira et al., 2017]. In terms of mushroom metabolism, fatty acids are important as precursors of aromatic compounds; for example, linoleic acid is a precursor of the alcoholic compound 1-octen-3-ol, which gives mushrooms a specific aroma [Ribeiro et al., 2009].

Furthermore, according to Ribeiro et al. [2009], fatty acids may also exert anti-inflammatory, hypolipidemic and vasodilatory activities and may act preventively in cardiovascular diseases and hypertension, while Su et al. [2013] revealed that unsaturated fatty acids can delay the breakdown of carbohydrates in the intestine, thus preventing an increase in postprandial glucose levels and, possibly, managing symptoms of diabetes.

\section{Antioxidant activity of $C$. gambosa extract}

Regarding antioxidant properties, the $C$. gambosa extract has been evaluated via several in vitro assays. A comprehensive analysis of antioxidant activity (Table 3 ) included the following
TABLE 2. Chemical composition with regard to lipophilic compounds of Calocybe gambosa.

\begin{tabular}{|c|c|c|}
\hline Group & Compound & Content \\
\hline $\begin{array}{l}\text { Tocopherols } \\
(\mu \mathrm{g} / 100 \mathrm{~g} \mathrm{dw})\end{array}$ & $\alpha$-Tocopherol & $7.8 \pm 0.4$ \\
\hline & Caproic acid (C6:0) & $0.11 \pm 0.01$ \\
\hline & Caprylic acid (C8:0) & $0.07 \pm 0.01$ \\
\hline & Capric acid (C10:0) & $0.06 \pm 0.01$ \\
\hline & Lauric acid (C12:0) & $0.12 \pm 0.01$ \\
\hline & Myristic acid (C14:0) & $0.28 \pm 0.01$ \\
\hline & Myristoleic acid (C14:1) & $0.03 \pm 0.03$ \\
\hline & Pentadecanoic acid (C15:0) & $0.67 \pm 0.01$ \\
\hline & Palmitic acid (C16:0) & $13.2 \pm 0.2$ \\
\hline & Palmitoleic acid (C16:1) & $0.40 \pm 0.01$ \\
\hline & Heptadecanoic acid (C17:0) & $0.29 \pm 0.01$ \\
\hline & Stearic acid (C18:0) & $2.51 \pm 0.01$ \\
\hline & Oleic acid $(\mathrm{C} 18: \ln 9)$ & $3.43 \pm 0.01$ \\
\hline & Linoleic acid (C18:2n6) & $75.1 \pm 0.1$ \\
\hline \multirow{14}{*}{$\begin{array}{l}\text { Fatty acids } \\
\text { (\% total } \\
\text { fatty acids) }\end{array}$} & $\alpha$-Linoleic acid (C18:3n3) & $0.26 \pm 0.02$ \\
\hline & Arachidic acid (C20:0) & $0.14 \pm 0.01$ \\
\hline & Eicosenoic acid (C20:1) & $0.03 \pm 0.01$ \\
\hline & cis-11,14-Eicosatienoic acid (C20:2) & $0.08 \pm 0.01$ \\
\hline & $\begin{array}{l}\text { cis-11,14,17-Eicosatrienoic acid } \\
\text { and heneicosanoic acid } \\
(\mathrm{C} 20: 3 n 3+\mathrm{C} 21: 0)\end{array}$ & $0.29 \pm 0.04$ \\
\hline & $\begin{array}{c}\text { cis-5,8,11,14,17-Eicosapentaenoic acid } \\
\text { (C20:5n3) }\end{array}$ & $0.05 \pm 0.01$ \\
\hline & Behenic acid (C22:0) & $0.63 \pm 0.02$ \\
\hline & Behenic acid (C22:1n9) & $0.04 \pm 0.02$ \\
\hline & Tricosanoic acid (C23:0) & $0.70 \pm 0.01$ \\
\hline & Lignoceric acid (C24:0) & $1.41 \pm 0.09$ \\
\hline & Nervonic acid (C24:1) & $0.05 \pm 0.01$ \\
\hline & Total SFA & $20.2 \pm 0.1$ \\
\hline & Total MUFA & $3.98 \pm 0.03$ \\
\hline & Total PUFA & $75.8 \pm 0.1$ \\
\hline
\end{tabular}

Data represent mean \pm standard deviation; SFA: saturated fatty acids; MUFA: monounsaturated fatty acids; PUFA: polyunsaturated fatty acids; dw: dry weight.

assays: ferricyanide/Prussian blue assay, DPPH radical scavenging activity, $\beta$-carotene/linoleate assay and TBARS assay, which engage different mechanisms of action, implying the presence of more than one group of compounds with antioxidant potential. The results obtained indicate that the reducing power of the sample was significant $\left(\mathrm{EC}_{0.5}=0.89 \mathrm{mg} / \mathrm{mL}\right)$. Results of the other employed assays ( $\beta$-carotene/linoleate, DPPH radical scavenging activity and TBARS) indicate that the extract possessed antioxidant activity which varied 
TABLE 3. In vitro antioxidant activity of the Calocybe gambosa extract.

\begin{tabular}{lccc}
\hline Action mode & Antioxidant activity assay & C. gambosa & Trolox \\
\hline \multirow{2}{*}{ Reducing power } & Folin-Ciocalteu assay $(\mathrm{mg} \mathrm{GAE} / \mathrm{g}$ extract) & $29.9 \pm 0.1$ & - \\
& Ferricyanide/Prussian blue assay $\left(\mathrm{EC}_{0.5} ; \mathrm{mg} / \mathrm{mL}\right)$ & $0.89 \pm 0.02$ & $0.04 \pm 0.01$ \\
\hline Scavenging activity & DPPH radical scavenging activity $\left(\mathrm{EC}_{50} ; \mathrm{mg} / \mathrm{mL}\right)$ & $2.22 \pm 0.03$ & $0.04 \pm 0.01$ \\
\hline \multirow{2}{*}{ Lipid peroxidation inhibition } & $\beta$-Carotene/linoleate assay $\left(\mathrm{EC}_{50} ; \mathrm{mg} / \mathrm{mL}\right)$ & $1.3 \pm 0.2$ & $0.02 \pm 0.01$ \\
& TBARS assay $\left(\mathrm{EC}_{50} ; \mathrm{mg} / \mathrm{mL}\right)$ & $2.4 \pm 0.3$ & $0.02 \pm 0.01$ \\
\hline
\end{tabular}

Data represent mean \pm standard deviation. Concerning the Folin-Ciocalteu assay, higher values correspond to higher reducing power; for the other assays, the results are presented in $\mathrm{EC}_{0.5}$ or $\mathrm{EC}_{50}$, which means that higher values correspond to lower reducing power or antioxidant activity. $\mathrm{EC}_{05}$ : extract concentration corresponding to 0.5 of absorbance for the ferricyanide/Prussian blue assay; $\mathrm{EC}_{50}$ : extract concentration corresponding to $50 \%$ of antioxidant activity; GAE: gallic acid equivalent.

depending on the method used, but was lower in comparison to the positive control - Trolox (Table 3). Antioxidant activity may be correlated to the relatively high content of total phenolics in the extract determined with the Folin-Ciocalteu assay - $29.9 \mathrm{mg} \mathrm{GAE} / \mathrm{g}$ extract. Even though the data obtained on the antioxidant activity of $C$. gambosa extract are not exclusive, they are the most comprehensive, since they encompass four assays with different mechanisms of achieving antioxidant activity. This may eventually indicate the overall antioxidant potential of St. George mushroom. Previously, several authors reported the antioxidant potential of $C$. gambosa [Angelini et al., 2012; Barroetaveña \& Toledo, 2017; Vaz et al., 2011], though results of their investigations indicate its lower antioxidant potential compared to the sample analyzed in this study. Furthermore, a comparative antioxidant activity analysis of ethanolic and water extract with soluble polysaccharides conducted by Vaz et al. [2011], revealed that the extent of antioxidant activity depends not only on the type of the assay utilized for evaluation, but on the type of extract as well. For instance, the ethanolic extract exerted better DPPH radical scavenging activity than the water extract with soluble polysaccharides $\left(\mathrm{EC}_{50}=7.08 \mathrm{mg} / \mathrm{mL}\right.$ and $34.60 \mathrm{mg} / \mathrm{mL}$, respectively); whereas regarding the reducing power, the ethanolic extract showed $\mathrm{EC}_{05}$ of $11.46 \mathrm{mg} / \mathrm{mL}$ while the water extract showed $\mathrm{EC}_{0.5}$ of $0.18 \mathrm{mg} / \mathrm{mL}$. This implies that the antioxidant potential may be achieved through compounds other than the phenolics, such as high-molecular-weight polysaccharides identified in the water extract.

Given all the data, it may be concluded that the antioxidant potential depends on several factors: complex chemical environment, chemical constituents of the sample itself, but also on the type of the antioxidant assay employed. Even though it seems quite unrealistic to evaluate individual antioxidant potential of all the present components, it is known that the antioxidant activity of individual compounds does not necessarily reflect their overall antioxidant capacity (due to the possibility of synergistic/antagonistic interactions). In more details, since a number of diseases (atherosclerosis, cancer, diabetes, rheumatoid arthritis, post-ischemic perfusion injury, myocardial infarction, cardiovascular diseases, chronic inflammation etc.) have been associated to increased oxidative stress and overproduction of free radicals, the possibility of their mitigation and homeostasis maintenance with natural products seems to be a matter with high priority
[Ferreira et al., 2009; Carocho \& Ferreira, 2013]. Given this data, the assumption that a substance with antioxidant potential can be used as a prophylactic agent towards diseases whose etiology and progression are considered to be a consequence of oxidative stress, must be critically contemplated [Soobrattee et al., 2005].

\section{Antimicrobial activity of $C$. gambosa extract}

The results presented in Table 4 indicate that the $C$. gambosa extract exerts moderate to low antimicrobial activity. Among the tested bacterial and fungal strains, the best antimicrobial activity of extract was observed for the $S$. aureus (MIC $9.30 \mathrm{mg} / \mathrm{mL}, \mathrm{MBC} 18.60 \mathrm{mg} / \mathrm{mL}$ ) among bacteria, and $T$. viride and $A$. versicolor among micromycetes (MIC $10.94 \mathrm{mg} / \mathrm{mL}$, MFC $43.75 \mathrm{mg} / \mathrm{mL}$, for both species). The lowest antimicrobial potential was observed for M. luteus, L. monocytogenes, P. aeruginosa and E. coli (MIC $43.75 \mathrm{mg} / \mathrm{mL}$, MBC $87.50 \mathrm{mg} / \mathrm{mL}$ ) among bacteria and $P$. verrucosum var. cyclopium (MIC $29.12 \mathrm{mg} / \mathrm{mL}$, MFC $58.25 \mathrm{mg} / \mathrm{mL}$ ) among micromycetes.

Since its beginning, human society has been faced with the problem of diseases caused by pathogenic microorganisms. Although the discovery of antibiotics almost a century ago revolutionized the treatment of infectious diseases, today we once again face numerous multidrug-resistant strains that are very difficult to treat with available antimicrobial agents [Alves et al., 2013]. Many Gram-positive and Gram-negative bacteria have acquired mechanisms of resistance to antimicrobial agents including: Shigella sp., Salmonella sp., Escherichia coli, Enterococcus faecium, as well as respiratory pathogens Klebsiella pneumoniae and $P$. aeruginosa. Experimental data indicate that exposure of bacteria to low concentrations of tetracycline leads to a 100 -fold increase in gene transfer whose products increase resistance [Wilson et al., 2002]. Furthermore, infections caused by micromycetes have been particularly expanding in recent years, due to an increased number of immunocompromised patients, with selective and toxic antifungal drugs used in clinical practice, indicating desperate need for new effective agents among which mushrooms turned out to be very perspective. As for the literature data on the antimicrobial potential of $C$. gambosa, they indicate antibacterial activity towards E. coli and Bacillus subtilis [Vaz et al., 2011] and antifungal activity of an ethyl acetate extract prepared from broth, against 33 (5 yeasts and 28 filamentous fungi) clinically relevant 
TABLE 4. Antibacterial and antifungal activity of the Calocybe gambosa methanolic extract.

\begin{tabular}{|c|c|c|}
\hline Bacteria & $\begin{array}{c}\mathrm{MIC} \\
(\mathrm{mg} / \mathrm{mL})\end{array}$ & $\begin{array}{c}\mathrm{MBC} \\
(\mathrm{mg} / \mathrm{mL})\end{array}$ \\
\hline Staphylococcus aureus (ATCC 6538) & $9.30 \pm 0.01$ & $18.60 \pm 0.01$ \\
\hline Bacilus cereus (clinical isolate) & $10.94 \pm 0.01$ & $21.88 \pm 0.01$ \\
\hline Micrococcus luteus (ATCC 10240) & $43.75 \pm 0.01$ & $87.50 \pm 0.01$ \\
\hline Listeria monocytogenes (NCTC 7973) & $43.75 \pm 0.01$ & $87.50 \pm 0.01$ \\
\hline Pseudomonas aeruginosa (ATCC 27853) & $43.75 \pm 0.01$ & $87.50 \pm 0.01$ \\
\hline Enterobacter cloacae (human isolate) & $10.94 \pm 0.01$ & $21.88 \pm 0.01$ \\
\hline Salmonella Typhimurium (ATCC 13311) & $10.94 \pm 0.01$ & $21.88 \pm 0.01$ \\
\hline Escherichia coli (ATCC 35210) & $43.75 \pm 0.01$ & $87.50 \pm 0.01$ \\
\hline Fungi & $\begin{array}{c}\mathrm{MIC} \\
(\mathrm{mg} / \mathrm{mL})\end{array}$ & $\begin{array}{c}\mathrm{MFC} \\
(\mathrm{mg} / \mathrm{mL})\end{array}$ \\
\hline Aspergillus ochraceus (ATCC 12066) & $21.88 \pm 0.01$ & $43.75 \pm 0.01$ \\
\hline Aspergillus fumigatus (ATCC 1022) & $21.88 \pm 0.01$ & $43.75 \pm 0.01$ \\
\hline Aspergillus niger (ATCC 6275) & $21.88 \pm 0.01$ & $43.75 \pm 0.01$ \\
\hline Aspergillus versicolor (ATCC 11730) & $10.94 \pm 0.01$ & $43.75 \pm 0.01$ \\
\hline Penicillium funiculosum (ATCC 36839) & $21.88 \pm 0.01$ & $43.75 \pm 0.01$ \\
\hline Penicillium ochrochloron (ATCC 9112) & $21.88 \pm 0.01$ & $43.75 \pm 0.01$ \\
\hline $\begin{array}{l}\text { Penicillium verrucosum var. } \\
\text { cyclopium (food isolate) }\end{array}$ & $29.12 \pm 0.01$ & $58.25 \pm 0.01$ \\
\hline Trichoderma viride (IAM 5061) & $10.94 \pm 0.01$ & $43.75 \pm 0.01$ \\
\hline
\end{tabular}

Data represent mean \pm standard deviation; MIC: minimal inhibitory concentration; MBC: minimal bactericidal concentration; MFC: minimal fungicidal concentration.

fungal strains [Angelini et al., 2012]. Among the tested strains, C. albicans (DBVPG 4268) strain turned out to be the most susceptible to the activity of the extract. MIC values were significantly lower than those obtained in our study and ranged from 1.56 to $12.5 \mu \mathrm{g} / \mathrm{mL}$, with better observed activity in comparison to fungicide amphotericin B (positive control). Altogether, the obtained data imply that $C$. gambosa may be a source of bioactive compounds important in the food industry, pharmacy and drug development.

\section{Anti-quorum sensing activity of $\boldsymbol{C}$. gambosa extract}

A more detailed assessment of possible mechanisms underlying the determined antibacterial activity towards $P$. aeruginosa PAO1 revealed that the $C$. gambosa extract efficiently interfered within bacterial cell-to-cell communication. This was measured on the morphological (motility changes) and physiological (changes in the production of pigment pyocyanin) level. Speaking of the colony appearance, the results obtained indicate that the control colony of $P$. aeruginosa PAO1 appeared with rough edges due to the presence of a series of TIVP needed for colony dispersal (Figure 1C). $P$. aeruginosa $\mathrm{PAO} 1$ colony incubated with the $C$. gambosa methanolic extract $(0.5 \mathrm{MIC}-21.9 \mathrm{mg} / \mathrm{mL})$ strongly inhibited the formation of TIVP as was indicated by the complete reduction of these structures (Figure 1D). Moreover, commercial antibiotics: streptomycin and ampicillin, selectively inhibited the dispersion of $P$. aeruginosa PAO1 colony: streptomycin completely reduced motility structures, whereas ampicillin was less efficient (Figure 1A and Figure 1B). Production of pyocyanin was lower (Figure 2) in the presence of the $C$. gambosa methanolic extract compared to level of this virulence factor in the control pyocyanin sample (indicating the extract may alter the pathway of its production, making it the perspective anti-QS agent.

Results of anti-QS activity - a decrease in colony diameter, along with a change in TIVP number and colony color, may indicate that the extract effectively affects the QS-regulated functions in $P$. aeruginosa PAO1, since it limits the colony dispersion which is crucial for the expansion of the pathogen. Furthermore, a change measured in the production of pyocyanin, which is a known virulence factor, may also indicate interference of molecules present in the extract with the physiology of $P$. aeruginosa PAO1. A decrease in pyocyanin production (Figure 2) in the presence of subMIC of the $C$. gambosa methanolic extract strongly supports this fact.

Numerous compounds identified in mushroom extracts turned out to be efficient inhibitors of QS-regulated functions. For example, Soković et al. [2014] reported that the aqueous extract of Agaricus blazei reduced pyocyanin production, motility, and biofilm formation of $P$. aeruginosa PAO1, while Zhu et al. [2011] demonstrated that pigments extracted from the basidiocarp of Auricularia auricular, inhibited production

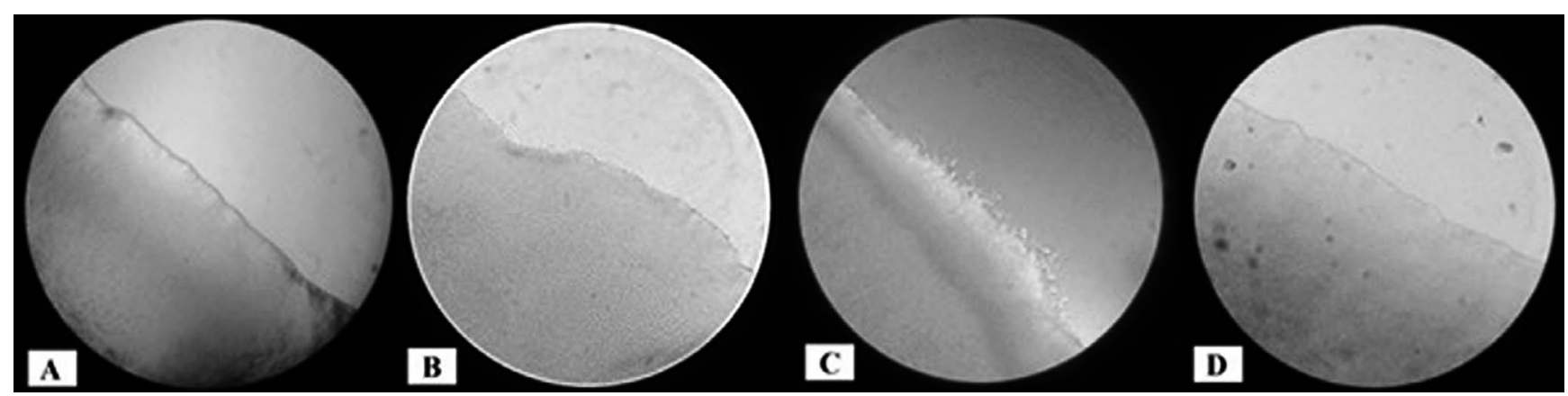

FIGURE 1. Light microscopic images of colony edges of Pseudomonas aeruginosa PAO1 twitching motibility plates, grown in the presence of antibiotics $(0.10 \mathrm{mg} / \mathrm{mL})$ or $0.5 \mathrm{MIC}$ Calocybe gambosa extract $(21.9 \mathrm{mg} / \mathrm{mL})$. The colonies of bacteria grown in the presence of streptomycin (A) and ampicillin (B) show flat edges and slight reduction in the number and diameter of type IV pili (TIVP) structures for colony dispersal, respectively. Image (C) shows edge of colony with fully grown pili (control without inhibitors), whereas image (D) reveals flat surface indicating their complete reduction with C. gambosa extract. Magnification (A-D) $\times 100$. 


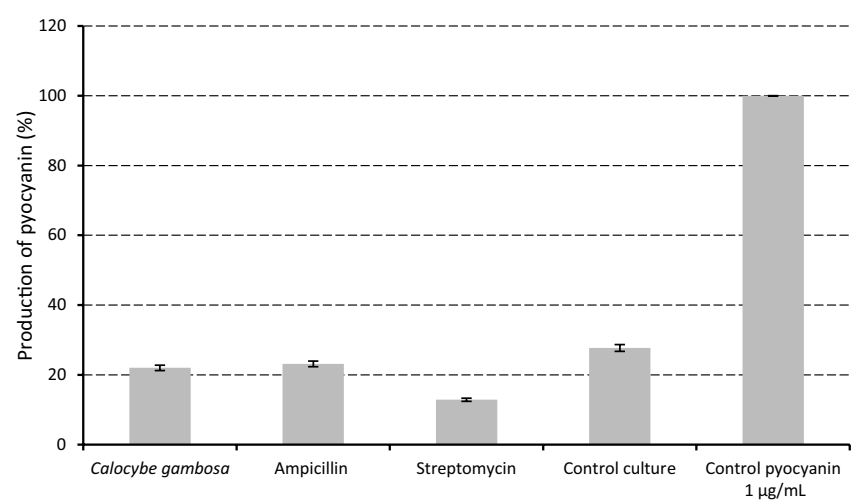

FIGURE 2. Production of pyocyanin by Pseudomonas aeruginosa PAO1 in the presence of $0.5 \mathrm{MIC}$ Calocybe gambosa extract $(21.9 \mathrm{mg} / \mathrm{mL})$, positive controls: ampicillin and streptomycin $(0.10 \mathrm{mg} / \mathrm{mL})$ and without inhibitors (control).

of a pigment - violacein (also a virulence factor). The antiQS activity of compounds of natural origin, as demonstrated in this study, is, in fact, a potentially new pathway to control the diseased caused by P. aeruginosa PAO1.

\section{Sensory and nutritional evaluation of cookies with C. gambosa}

Results of the determination of the nutritional value of oatmeal cookies enriched with $C$. gambosa flakes and their sensory evaluation are presented in Table 5. In general, the newly designed product was positively assessed by the evaluation group. Our attempt to harness various aspects of science and food industry into designing cookies was accepted by the respondents. The score that the enriched product gained was higher than the one obtained for the oatmeal cookie alone, pointing out that participants liked a bit more the new product enriched with mushroom flakes in comparison to the cookies without them - at least in terms of their appearance, aroma, taste and consistency (Table 5). Development of new food products enriched with ingredients of natural origin (in this case mushrooms) with biological activity has been a trend in both science and food industry for quite some time [Soković et al., 2017]. For example, previously published results indicate that the chestnut mushroom (Agrocybe aegerita) fits very-well with cream cheese, or that button mushroom (Agaricus bisporus) may be used as a natural preservative in yoghurt [Petrović et al., 2015; Stojković et al., 2014]. Having in mind that the results obtained point out that $C$. gambosa has a desirable nutrient profile and bioactive compound contents (Tables 1-3), the mushroom may be considered a candidate for nutraceutical or functional food ingredient. However, for future reference, the consumption of both nutritive and non-nutritive compounds through food has to be observed within the context of their bioavailability in the gastro-intestinal system, which is related to the gut microbiota [Vamanu \& Gatea, 2020]. Possible changes in the bioactivity of the compounds, which stem from the gut microbiota activity or chemical modifications due to their metabolic pathway, are potential key limiting factors in using the bioactive compounds for health-beneficial purposes.

An up-to-date literature survey showed that there is a growing interest in investigating the influence of the bioactive
TABLE 5. Nutritional value and sensory evaluation of oatmeal cookies enriched with Calocybe gambosa flakes.

\begin{tabular}{lcc}
\hline & $\begin{array}{c}\text { Cookie enriched with } \\
\text { C. gambosa flakes }\end{array}$ & $\begin{array}{c}\text { Cookie without } \\
\text { C. gambosa } \text { (control) }\end{array}$ \\
\hline $\begin{array}{l}\text { Fat } \\
(\mathrm{g} / 100 \mathrm{~g} \mathrm{dw})\end{array}$ & 3.40 & 3.37 \\
$\begin{array}{l}\text { Proteins } \\
(\mathrm{g} / 100 \mathrm{~g} \mathrm{dw})\end{array}$ & 1.82 & 1.47 \\
$\begin{array}{l}\text { Carbohydrates } \\
(\mathrm{g} / 100 \mathrm{~g} \mathrm{dw})\end{array}$ & 14.95 & 13.47 \\
$\begin{array}{l}\text { Energy } \\
(\mathrm{kcal} / 100 \mathrm{~g} \mathrm{dw})\end{array}$ & 98.57 & 90.98 \\
\hline Appearance & $4.66 \pm 0.48$ & $4.25 \pm 0.74$ \\
Aroma & $4.25 \pm 0.74$ & $4.25 \pm 0.74$ \\
Taste & $4.66 \pm 0.48$ & $4.25 \pm 0.74$ \\
Consistency & $4.83 \pm 0.38$ & $4.54 \pm 0.51$ \\
$\begin{array}{l}\text { Overall } \\
\text { acceptability }\end{array}$ & $4.68 \pm 0.64$ & $4.24 \pm 0.68$ \\
\hline
\end{tabular}

The results of sensory evaluation are expressed as mean of grades given by the untrained participants \pm standard deviation $(n=24)$. Grading scale: 1 - extremely dislike; 2 - dislike; 3 - neither like nor dislike; 4 - like; 5 - extremely like.

compounds onto the gut microbiota - hence the future research should focus on this aspect. This is supported by a recent study by Li et al. [2021], which indicates that the application of different mushrooms, such as Lentinula edodes, Hericium erinaceus, Grifola frondosa, Ganoderma lucidum, positively affects gut microbiota. This has been validated by using experimental animals fed with Bulgaria inquinans; after a course of treatment, the status of their gut microbiota has been significantly improved [Sang et al., 2020]. Among the identified compounds from mushrooms, non-digestable carbohydrates had a profound impact on the gut microbiota, leading to its restoration in individuals suffering from dysbiosis [Ma et al., 2021]. Aside from carbohydrates, phenolic compounds are also considered valuable ingredients which improve the gut microbiota status [Mithul Aravind et al., 2021].

\section{CONCLUSION}

This study took a step forward towards assessing mushroom's potential to be regarded as functional food, using cookie as a food matrix. The developed cookie product was praised among the participants in sensory evaluation, in terms of appearance, aroma, taste, consistency and overall acceptability. In the long run, this data may be of interest for the market, hence further research should be directed towards this. To summarize, the results obtained in this study provide fresh perspective on using wild growing mushrooms as a valuable source of both nutritive and bioactive compounds, which may confer beneficial health effects as well. The favorable profile of macronutrients, coupled with the presence of $\alpha$-tocopherol, free sugars, organic and fatty acids indicate that $C$. gambosa is a desirable food in several dietary regimens. Results of determinations of bioactive properties suggest that some of the identified compounds may be responsible for antioxidant, antimicrobial and anti-QS potentials. Moreover, 
they point to the fact that mushrooms have a great potential in both pharmaceutical and food industry, due to the presence of several groups of compounds. Unique and versatile organoleptic properties of mushrooms allow them to fit very well with both sweet and savory ingredients, which was the basic presumption of this study after all. As a result, the developed cookie enriched with mushroom flakes was perceived by sensory assessment participants as delicious.

\section{RESEARCH FUNDING}

This research was funded by the Ministry of Education, Science and Technological Development of the Republic of Serbia, grant number 451-03-9/2021-14/ 200007. The authors acknowledge the Foundation for Science and Technology (FCT, Portugal) for financial support by national funds FCT/MCTES to CIMO (UIDB/00690/2020).

\section{CONFLICT OF INTERESTS}

Authors declare no conflict of interests.

\section{ORCID IDs}

L. Barros https://orcid.org/0000-0002-9050-5189

Â. Fernandes https://orcid.org/0000-0002-0157-9873

I.C.F.R. Ferreira https://orcid.org/0000-0003-4910-4882

J. Glamočlija https://orcid.org/0000-0001-6823-1137

J. Petrović https://orcid.org/0000-0002-9016-9971

A. Shekhar https://orcid.org/0000-0001-7383-6050

M. Soković https://orcid.org/0000-0002-7381-756X

D. Stojković https://orcid.org/0000-0002-4159-1471

\section{REFERENCES}

1. Alves, M., Ferreira, I.F.R., Dias, J., Teixeira, V., Martins, A. Pintado, M. (2012). A review on antimicrobial activity of mushroom (Basidiomycetes) extracts and isolated compounds. Planta Medica, 78, 1707-1718.

https://doi.org/10.1055/s-0032-1315370

2. Alves, M.J., Ferreira, I.C.F.R., Froufe, H.J.C., Abreu, R.M.V, Martins, A., Pintado, M. (2013). Antimicrobial activity of phenolic compounds identified in wild mushrooms, SAR analysis and docking studies. Journal of Applied Microbiology, 115, 346-357.

https://doi.org/10.1111/jam.12196

3. Angelini, P., Tirillini, B., Venanzoni, R., (2012). In vitro antifungal activity of Calocybe gambosa extracts against yeasts and filamentous fungi. African Journal of Microbiology Research, 6, 1810-1814. https://doi.org/10.5897/AJMR11.1384

4. AOAC (2016). Official Methods of Analysis of AOAC International. Official Methods of Analysis of AOAC International; AOAC International: Gaithersburg, MD, USA.

5. Barroetaveña, C., Toledo, C.V. (2017). The nutritional benefits of mushrooms. Chapter 3, In: I.C.F.R. Ferreira, P. Morales, L. Barros (Eds)., Wild Plants, Mushroom and Nuts. Functional Food Properties and Applications. Wiley Blackwell, pp. 65-81. https://doi.org/10.1002/9781118944653.ch3

6. Barros, L., Calhelha, R.C., Vaz, J.A., Ferreira, I.C.F.R., Baptista, P., Estevinho, L.M. (2007). Antimicrobial activity and bioactive compounds of Portuguese wild edible mushrooms methanolic extracts. European Food Research and Technology, 225, 151-156. https://doi.org/10.1007/s00217-006-0394-x

7. Barros, L., Pereira, C., Ferreira, I.C.F.R. (2013). Optimized analysis of organic acids in edible mushrooms from Portugal by ultrafast liquid chromatography and photodiode array detection. Food Analytical Methods, 6, 309-316.

https://doi.org/10.1007/s12161-012-9443-1

8. Beluhan, S., Ranogajec, A. (2011). Chemical composition and non-volatile components of Croatian wild edible mushrooms. Food Chemistry, 124, 1076-1082.

https://doi.org/10.1016/j.foodchem.2010.07.081

9. Carocho, M., Ferreira, I.C.F.R. (2013). A review on antioxidants, prooxidants and related controversy: Natural and synthetic compounds, screening and analysis methodologies and future perspectives. Food \& Chemical Toxicology, 51, 15-25.

https://doi.org/10.1016/j.fct.2012.09.021

10. CLSI (2009). Clinical and Laboratory Standards Institute Methods for dilution antimicrobial susceptibility tests for bacteria that grow aerobically. In: Approved standard, $8^{\text {th }}$ ed. CLSI publication M07-A8. Clinical and Laboratory Standards Institute, Wayne, PA, USA.

11. El Fouly, M.Z., Sharaf, A.M., Shahin, A.A.M., El-Bialy, H.A., Omara, A.M.A. (2015). Biosynthesis of pyocyanin pigment by Pseudomonas aeruginosa. Journal of Radiation Research and Applied Sciences, 8, 36-48.

https://doi.org/10.1016/j.jrras.2014.10.007

12. Ferreira, I.C.F.R., Barros, L., Abreu, R. (2009). Antioxidants in wild mushrooms. Current Medicinal Chemistry, 16(12), 1543-1560.

https://doi.org/10.2174/092986709787909587

13. Heleno, S., Barros, L., Sousa, M., Martins, A., Ferreira, I.C.F.R. (2010). Tocopherols composition of Portuguese wild mushrooms with antioxidant capacity. Food Chemistry, 119(4), 1443-1450. https://doi.org/10.1016/j.foodchem.2009.09.025

14. Li, M., Leilei, Y., Zhao, J., Zhang, H., Chen, W., Zhai, Q., Fengwei, T. (2021). Role of dietary edible mushrooms in the modulation of gut microbiota. Journal of Functional Foods, 83, art. no. 104538 .

https://doi.org/10.1016/j.jff.2021.104538

15. Ma, G.X., Du, H.J., Hu, Q.H., Yang, W.J., Pei, F., Xiao, H. (2021). Health benefits of edible mushroom polysaccharides and associated gut microbiota regulation. Critical Reviews in Food Science and Nutrition.

https://doi.org/10.1080/10408398.2021.1903385

16. Mithul Aravind, S., Wichienchot, S., Tsao, S., Ramakrishnan, S., Chakkaravarthi, S. (2021). Role of dietary polyphenols on gut microbiota, their metabolites and health benefits. Food Research International, 142, art. no. 110189.

https://doi.org/10.1016/j.foodres.2021.110189

17. Mridu, C., Atri, N.S. (2017). Nutritional and nutraceutical characterization of three wild edible mushrooms from Haryana, India. Mycosphere, 8(8), 1035-1043.

https://doi.org/10.5943/mycosphere/8/8/4

18. Petrović, J., Glamoclija, J., Stojković, D., Ciric, A., Barros, L., Ferreira, I., Soković, M. (2015). Nutritional value, chemical composition, antioxidant activity and enrichment of cream cheese with chestnut mushroom Agrocybe aegerita (Brig.) Sing. Journal of Food Science and Technology Mysore, 52, 6711-6718.

https://doi.org/10.1007/s13197-015-1783-6 
19. Petrović, J., Glamočlija, J., Ilić-Tomić, T., Soković, M., Robajac, D., Nedić, O., Pavić, A. (2020). Lectin from Laetiporus sulphureus effectively inhibits angiogenesis and tumor development in the zebrafish xenograft models of colorectal carcinoma and melanoma. International Journal of Biological Macromolecules, 148, 129-139.

https://doi.org/10.1016/j.ijbiomac.2020.01.033

20. Rathee, S., Rathee, D., Rathee, D., Kumar, V., Rathee, P. (2012). Mushrooms as therapeutic agents. Revista Brasileira de Farmacognosia, 22, 459-474.

https://doi.org/10.1590/s0102-695X2011005000195

21. Reis, F.S., Barros, L., Martins, A., Ferreira, I.C.F.R. (2012a). Chemical composition and nutritional value of the most widely appreciated mushrooms: an inter-species comparative study. Food \& Chemical Toxicology, 50, 191-197.

https://doi.org/10.1016/j.fct.2011.10.056

22. Reis, F.S., Martins, A., Barros, L., Ferreira, I.C.F.R. (2012b). Antioxidant properties and phenolics profile of the most widely appreciated cultivated mushrooms: a comparative study between in vivo and in vitro samples. Food \& Chemical Toxicology, 50, 1201-1207.

https://doi.org/10.1016/j.fct.2012.02.013

23. Ribeiro, B., Guedes de Pinho, P., Andrade, P.B., Baptista, P., Valentão, P. (2009). Fatty acid composition of wild edible mushrooms species: A comparative study. Microchemical Journal, 93, $29-35$

https://doi.org/10.1016/j.microc.2009.04.005

24. Sang, H., Xie, Y., Su, X., Zhang, M., Zhang, Y., Liu, K., Wang, J. (2020). Mushroom Bulgaria inquinans modulates host immunological response and gut microbiota in mice. Frontiers in Nutrition, 7, art. no. 144.

https://doi.org/10.3389/fnut.2020.00144.

25. Soković, M., Ćirić, A., Glamočlija, J., Nikolić, M., Griensven, L.J.L.D. (2014). Agaricus blazei hot water extract shows anti quorum sensing activity in the nosocomial human pathogen Pseudomonas aeruginosa. Molecules, 19(4), 4189-4199.

https://doi.org/10.3390/molecules19044189

26. Soković, M., Ćirić, A., Glamočlija, J., Stojković, D. (2017). The bioactive properties of mushrooms. Chapter 4, In: I.C.F.R. Ferreira, P. Morales, L. Barros (Eds)., Wild Plants, Mushroom and Nuts. Functional Food Properties and Applications. Wiley Blackwell, pp. 83-122.

https://doi.org/10.1002/9781118944653.ch4

27. Soobrattee, M.A., Neergheen, V.S., Luximon-Ramma, A., Aruoma, O.I., Bahorun, T. (2005). Phenolics as potential antioxidant therapeutic agents: mechanism and actions. Mutation Research/Fundamental and Molecular Mechanisms of Mutagenesis, 579(1-2), 200-213. https://doi.org/10.1016/j.mrfmmm.2005.03.023

28. Stojković, D., Reis, F., Glamoclija, J., Ciric, A., Barros, L., Van Griensven, L., Ferreira, I., Soković, M. (2014). Cultivated strains of Agaricus bisporus and A. brasiliensis: Chemical characterization and evaluation of antioxidant and antimicrobial properties for the final healthy product-natural preservatives in yoghurt. Food \& Function, 5, 1602-1612.

https://doi.org/10.1039/c4fo00054d

29. Su, C.H., Laib, M.N., Ng, L.T. (2013). Inhibitory effects of medicinal mushrooms on $\alpha$-amylase and $\alpha$-glucosidase - enzymes related to hyperglycemia. Food \& Function, 4, 644-649.

https://doi.org/10.1039/c3fo30376d

30. Valverde, M.E., Hernández-Pérez, T., Paredes-López, O. (2015). Edible mushrooms: improving human health and promoting quality life. International Journal of Microbiology, 2015, art. no. 376387.

https://doi.org/10.1155/2015/376387

31. Vamanu, E., Gatea, F. (2020). Correlations between microbiota bioactivity and bioavailability of functional vompounds: A miniteview. Biomedicines, 8(2), art. no. 39.

https://doi.org/10.3390/biomedicines8020039

32. Vaz, A.J., Heleno, S.A., Martins, A., Almeida, M.G., Vasconcelos, M.H., Ferreira, I.C.F.R. (2010). Wild mushrooms Clitocybe alexandri and Lepista inversa: In vitro tumor cell lines. Food \& Chemical Toxicology, 48(10), 2881-2884.

https://doi.org/10.1016/j.fct.2010.07.021

33. Vaz, J., Barros, L., Martins, A., Santos-Buelga, C., Vasconcelos, H.M., Ferreira, I.C.F.R. (2011). Chemical composition of wild edible mushrooms and antioxidant properties of their water soluble polysaccharidic and ethanolic fractions. Food Chemistry, 126(2), 610-616.

https://doi.org/10.1016/j.foodchem.2010.11.063

34. Wasser, S. (2014). Medicinal mushroom science: Current perspectives, advances, evidences, and challenges. Biomedicinal Journal, 37(6), 345-356.

https://doi.org/10.4103/2319-4170.138318

35. Wilson, J.W., Schurr, M.J., LeBlanc, C.L., Ramamurthy, R., Buchanan, K.L., Nickerson, C.A. (2002). Mechanisms of bacterial pathogenicity. Postgraduate Medical Journal, 78, 216-224. https://doi.org/10.1136/pmj.78.918.216

36. Yeo, S.S.M., Tham, F.Y. (2012). Anti-quorum sensing and antimicrobial activities of some traditional Chinese medicinal plants commonly used in South-East Asia. Malaysian Journal of Microbiology, 8, 11-20.

https://doi.org/10.21161/mjm.34911

37. Zhong, J.H.X. (2009). Secondary metabolites from higher fungi: Discovery, bioactivity and bioproduction. Advances in Biochemical Engineering/Biotechnology, 113, 79-150.

https://doi.org/10.1007/10_2008_2

38. Zhu, H, He, C.C., Chu, Q.H., (2011). Inhibition of quorum-sensing in Chromobacterium violaceum by pigments from Auricularia auricular. Letters in Applied Microbiology, 52, 269-274. https://doi.org/10.1111/j.1472-765X.2010.02993.x 